ticularly remarkable for their time and locality, avoided magical formulæ or miraculous faith-cures. It may be surmised that they modelled themselves on the practice of Moslem and Hebrew physicians. Their literary activity stopped with the sack of Salerno in 1196 ; but the famous edict of Frederick II regulating the practice of medicine was issued in 1240 when a "College" had been formed. The Regimen Salernitatum in its original form was not particularly important medically; when it became popular, it was altered by others; the significant Salernitan writings were Copho, Antidotarium, Trotula and Rolandina. The essential achievement of the Salernitans was the advancement of medical practice on those professional lines which it had preserved to the present day.

\section{Stone Age Cilicia}

A REMARKABLE prospect of the future which will lie open to intensive archæological investigation in Cilicia was given by Mr. Miles C. Burkitt in a report recently presented (May 7) to the Royal Anthropological Institute on his examination of the stone industries of the lower levels found at Tell Halaf, near Mersin. This Tell, which is being explored by the Neilson Expedition under Prof. J. G. Garstang (see Nature, 143, 464; 1939), has proved to be one of the most important sites in the Near East. Mr. Burkitt's examination of the lower levels by a terrace excavation beginning at the lower limit of the Tell Halaf culture, and extending downward nearly to river-level, has revealed a proto-chalcolithic culture with deposits of 3 metres depth, and below this an upper and lower neolithic of 9 metres together.

Each of these deposits has yielded a characteristic pottery, of which the chalcolithic is a painted ware, some reminiscent of Nineveh, while other sherds resemble painted pottery of Thessaly. In this level mudbrick was in use and there was a poor industry of obsidian and chert. In the Upper Neolithic level the pottery was fine but undecorated. Mud-brick was not in use, while obsidian implements were more numerous than in the higher level. The pottery of the Lower Neolithic consists of hole-mouthed vessels of softer, coarser ware, which are well burnished and frequently show an incised decoration. Similar wares at present have been found only at Ras. Shamra in the lowest levels. The obsidian industry is striking and includes beautiful lance-heads and daggers, flaked by pressure. These industries antedate anything hitherto discovered in this part of the Near East. In Mr. Burkitt's opinion these discoveries auger well for the prospects of the discovery of late Paleolithic industries in the many rock shelters to be explored in the foothills of Taurus bordering Cilicia.

\section{Wolf-Children}

IN his presidential address on this subject delivered before the Folk-Lore Society on February 21 (FolkLore, 51,9 ; 1940), Dr. J. H. Hutton deals with the cases recorded from classical antiquity down to the present time of children having been reared by animals, especially wolves. The earliest record of a wolf-child which he has discovered in northern Europe is that reported by William Dilich in 134l as occurring in Hesse. Two Lithuanian cases of wolfchildren were described by Connor in his "History of Poland", published in 1698, since when no cases have been described in Europe. Many recent cases, how. ever, have been reported from India, mostly from the United Provinces, and also from Central India, as well as from Africa.

Wolves are not the only animals which have been said to have carried off and suckled children. In classical antiquity, Atalanta is stated to have been suckled by a bear and Cyrus by a bitch, while in recent times bear-children, jaguar- and leopardchildren have been recorded in India, and lionchildren and a baboon-child in Africa. It is a remarkable fact that no stories of the kind have been reported from the New World, where examples of wolf- and bear-children might have been expected from North America and jaguar- and puma-children from South America. Although it has been suggested that wolf-children are idiots who have wandered into the jungle and taken up their abode in the dens of wolves, this hypothesis is by no means universally applicable, notably in the case of the jaguar-child in the North Cachar Hills, India. Dr. Hutton comes to the conclusion that the evidence from India of wolf- and leopard-children and from Africa of a baboon-child seems to support the hypothesis that the belief is founded on observed facts.

\section{Research at Port Erin}

The report for 1939 (No. 52) of the Marine Biological Station at Port Erin, Isle of Man, drawn up by the director, Prof. J. H. Orton, shows that the oyster investigations and other researches have been continued and that the director submitted to the Manx Government a memorandum on the prospect of the development of an oyster fishery in the neighbourhood of the Isle of Man. It is stated that during the past year pressure of work caused Dr. R. J. Daniel to resign his directorship. Arrangements are being made for the transfer of the direction of the Station from the Department of Oceanography to the Department of Zoology in the University of Liverpool.

The new plans for the development of the Station unfortunately have all been temporarily cancelled owing to the War. These include increase of staff, new tanks, more efficient pumps, electricity for light and power, a store hut on the quay for gear, and funds acquired to keep the motor-boat continuously in commission and available for all research workers. It is to be hoped that these additions are merely postponed and that a successful future will be assured for this laboratory which has produced so much good work.

\section{Swiss Short-Wave Emissions}

AN article by Paul Borsinger, chief of the Swiss short-wave service, is published in Swiss Industry and Trade of May. The Swiss short-wave service was 